\title{
LEDENIK POD SKUTO KOT POKAZATELJ PODNEBNIH SPREMEMB V SLOVENSKEM DELU ALP
}

\author{
Miha Pavšek \\ Geografski inštitut Antona Melika ZRC SAZU, Novi trg 2, \\ SI-I000 Ljubljana, Slovenija \\ e-mail: miha.pavsek@zrc-sazu.si
}

Izvirni znanstveni članek

COBISS 1.01

\section{Izvleček}

Geografski inštitut Antona Melika ZRC SAZU že več kot šest desetletij opravlja redne meritve Triglavskega ledenika in ledenika pod Skuto. Oba ledenika se v zadnjem desetletju in pol intenzivno krčita. S krčenjem ledenika pod Skuto prihaja vse bolj do izraza pomen njegove senčne lege na vznožju okoliških ostenij. S primerjavo dinamike krčenja ledenika in izbranih meteoroloških kazalcev primerljivih opazovalnih postaj izpostavljamo pomen in stopnjo vplivanja podnebnih sprememb na ta, najbolj jugovzhodno ležeč ledenik na območju Alp.

Ključne besede: ledeniki, ledeniška dinamika, podnebne spremembe, Kamniško-Savinjske Alpe, Slovenija.

\section{THE SKUTA GLACIER AS AN INDICATOR OF CLIMATE CHANGES IN SLOVENIAN PART OF THE ALPS}

\begin{abstract}
The Anton Melik Geographical Institute SRC SASA provide the regular annual measurements of Triglav and Skuta glaciers for more than six decades. Both glaciers show a permanent retreat. Last measurements undoubtedly confirm the importance of the glacier shady position at the foothills of the surrounding walls. Comparison of glacier characteristics with some meteorological data helps us to recognize the influence of climate changes on this, most southeastern lying glaciers in the Alps.
\end{abstract}

Key words: glaciers, glacier dynamics, climate changes, Kamnik-Savinja Alps, Slovenia. 


\section{UVOD}

Ledenik pod Skuto je poleg Triglavskega ledenika najbolj jugovzhodno ležeči ledenik v Alpah. Leži v Kamniško-Savinjskih Alpah, natančneje nad strmim zatrepom Ravenske kočne jugovzhodno od naselja Zgornje Jezersko. Z ostenji obdano in večji del leta senčno krnico nad Ledinami, v kateri je ledenik, zaključuje greben med Kranjsko Rinko (2453 m) in Skuto (2532 m). Zaradi lege na sorazmerno nizki nadmorski višini med 2020 in $2120 \mathrm{~m}$ je še posebej občutljiv na podnebne spremembe. Zanimivost pojava, njegova bližina in zavarovanih plezalnih poti vajenih obiskovalcev so povzročili, da je bil že od nekdaj pred-met zanimanja tudi med gorniki, še posebej geografi, saj gre za pomemben objekt naše hidrološko-geomorfološke naravne dediščine.

Prve uradne meritve na ledeniku, v okviru takratnega Inštituta za geografijo SAZU, so opravili leta 1948, neuradne pa že dve leti prej. V zadnjem desetletju zbuja zanimanje predvsem kot eden od neposrednih kazalcev globalnih podnebnih sprememb in zaradi dejstva, da bo v naslednjem desetletju najverjetneje izginil. Kljub nižji nadmorski višini in snežni 'podhranjenosti' pa ga bo zaradi senčne lege doletelo to kasneje kot njegovega triglavskega soseda. V nadaljevanju se bomo seznanili z nekaterimi značilnostmi ledenika ter podatki, ki pričajo o podnebnih spremembah, ki smo jim priča predvsem v zadnjih dveh desetletjih. Ob zadnjih meritvah se je pokazalo, da je zdaj ledenik pod Skuto po površini večji od Triglavskega ledenika.

\section{ZNAČILNOSTI LEDENIKA KOT POKAZATELJA PODNEBNIH SPREMEMB}

Ledenik je večji del leta prekrit s snegom, proti koncu poletja pa je njegova površina delno ali v celoti razgaljena. Takrat lahko opazujemo nekatere ledeniške pojave, kot so ledeniške razpoke, grbine, luknje (lonce), vrata, firnski in ledeniški led, meandraste ledeniške škraplje ter ledeniške plastnice (Pavšek 2004). Pri življenju ga ohranja predvsem njegova osojna lega, saj leži v strmem (naklon 23-40) krniškem zatrepu, ki je odprt le proti severovzhodu, zato je več kot pol leta v celoti v senci (Slika 1). Napajajo ga neposredne snežne padavine in sneg, ki se osipa z ostenja nad njim. Precej snega odložijo predvsem močni vetrovi zahodne do južne smeri, po tem ko ga na privetrni strani grebena poberejo. V vpadnici žlebov in grap se občasno prožijo tudi snežni plazovi.

Na ledenik neprestano padajo manjši ali večji kamninski delci, še posebej iz prepokanega rdečkastega severovzhodnega dela ostenja Skute. Velik del površine je zato pogosto pod gruščem, kamenjem in manjšimi skalnim bloki. Zadnji večji podor nad vzhodnim delom ledenika je bil leta 2002. Stanje in obseg ledenika ter ledeniški in obledeniški pojavi so zelo odvisni od vsakoletnih vremenskih razmer ter nekaterih drugih naravnogeografskih sestavin, ki vplivajo na dogajanja $v$ redilni in talilni dobi. Hitro upadanje, ki se je začelo pred približno dvema desetletjema (avtor članka opravlja meritve od 1994 dalje) se je na prelomu stoletja prehodno upočasnilo, od leta 2003 pa se nadaljuje z nezmanjšano močjo. Na nekaterih delih je ledenik že povsem razkosan, kar omogoča še hitrejše krčenje. V letih z 
močno ablacijo lahko poleg lomljenja in razkosanja ledeniškega robu opazimo tudi povečano vboklost ledeniške površine. Izstopa zahodna polovica ledenika, kjer je ta najdebelejši.

Slika 1: Pogled na ledenik pod Skuto s sosednje Velike Babe (2127 m) med zadnjimi meritvami 15. oktobra 2007 (Foto: Bojan Pollak).

Figure 1: The Skuta glacier fromnearby peak of Velika Baba $(2127 \mathrm{~m})$ during the last measurements on October 15, 2007 (Photo: Bojan Pollak).

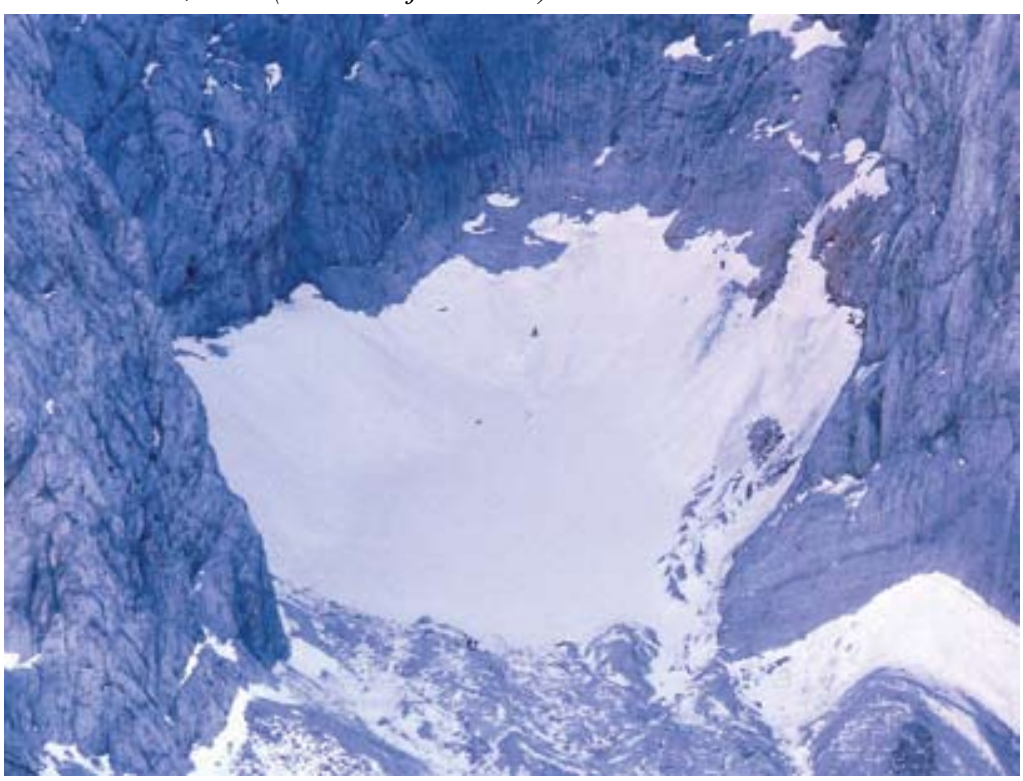

Skica previšanega horizonta (Slika 2) in poti sonca za najnižjo točko osrednjega dela ledenika (občasno seže nižje le zaradi snežnih plazov nastali ledeniški krak na njegovem zahodnem delu) nam kaže, da je ta sicer soncu najbolj izpostavljena točka vsako leto v senci več kot sedem mesecev. Natančneje, od začetka septembra vse do sredine aprila, višji deli ledenika pa še precej dlje. Najvišji deli ledenika na njegovem jugozahodnem delu so bili nekdaj v senci vse leto. Zaradi intenzivnega krčenja ledenika na njegovi najvišji in hkrati tudi najbolj osenčeni točki pa je v zadnjih letih ledeniška površina nekaj tednov okrog poletnega sončevega obrata v celoti osončena (Pavšek 1994-2007), če seveda to omogočajo vsakokratne vremenske razmere. 
Slika 2: Skica previšanega horizonta (črna črta) in poti Sonca (za obe enakonočji - zelena in solsticija - rdeča/modra) za osnovno stojišče pod osrednjim spodnjim robom ledenika (avtor: Blaž Komac).

Figure 2: Sketch of real horizon (black line) and the summer (red), winter (blue) solstice and equinox (green) Sun path diagram for the basic point below the central lower point of the glacier (Author: Blaž Komac).

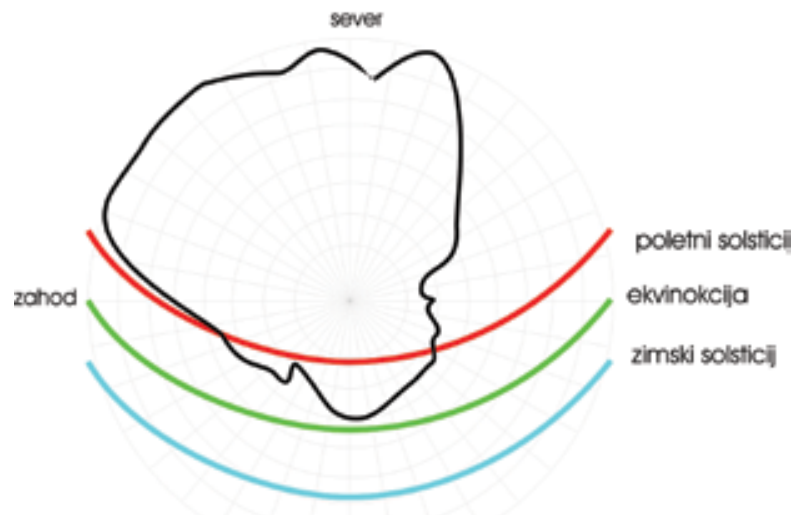

jug

\section{PODATKI O POVRŠINI LEDENIKA}

Ledenik pod Skuto, katerega površina (Preglednica 1) je bila kmalu po začetku meritev nekaj manj kot 3 hektare, je bil v drugi polovici 90. let 20. stoletja že prepolovljen. Ob zadnji geodetski izmeri leta 2007 pa je meril le še nekaj več kot tretjino površine, ki so jo namerili ob začetku meritev. Najmanjši obseg smo izmerili na koncu redilne dobe leta 2003 po rekordno vročem poletju (Spletni arhiv ARSO; Preglednica 5). Takrat se je ledenik močno zmanjšal, stanjšal in skrčil, previsni robovi na zgornjem delu so se začeli lomiti (Slika 3), približno četrtina ledeniške površine pa je bila pod gruščem, kamenjem in manjšimi skalnim bloki. Kljub vsemu pa je ledenik pod Skuto po zadnjih podatkih zdaj skoraj enkrat večji (1,1 ha) od Triglavskega ledenika (velikost 0,6 ha; september 2007).

Preglednica 1:Izbrani podatki o površini ledenika pod Skuto med letoma 1946 in 2007.

Table 1: Selected data of the Skuta glacier during the period 1946-2007.

\begin{tabular}{|l|r|}
\hline Leto & Površina (v ha) \\
\hline $1946-1954$ & $2,5-3,0$ \\
\hline 1950 & 2,8 \\
\hline Geodetska izmera 1997 & 1,5 \\
\hline Geodetska izmera 2003 & 0,7 \\
\hline Geodetska izmera 2007 & 1,1 \\
\hline
\end{tabular}

Vir: Arhiv GIAM ZRC SAZU. 
Slika 3: Zgornji rob ledenika ob koncu talilne dobe leta 2003 (foto: Miha Pavšek).

Figure 3: Upper edge of the glacier at the end ob ablation period in 2003 (Photo: Miha Pav̌̌ek).

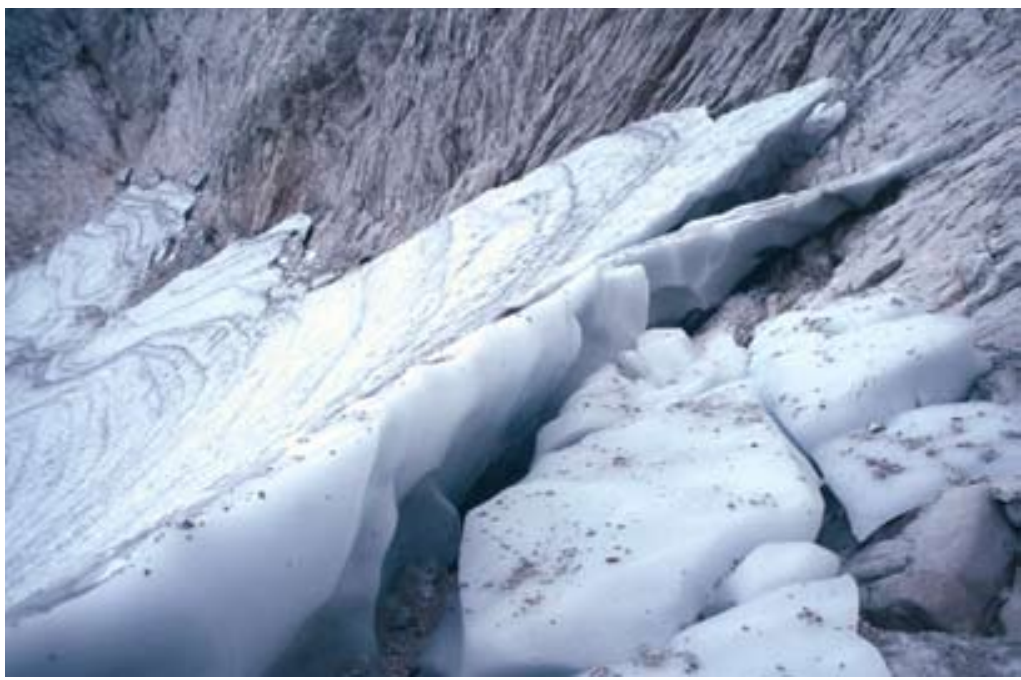

Ob meritvah 2005 smo opazili (Gabrovec in sod. 2005), da so posamezne zajede v rob ledenika, opažene dve leti prej in so značilne za začetno fazo razkroja ledenika (razkosanje), v glavnem izginile. Ledeniški obod je bil spet sklenjen. Sicer pa v zadnjem desetletju na ledeniku ni več večjih, vsaj $20 \mathrm{~cm}$ širokih ledeniških razpok in plastnic, njegova površina pa je pogosto v celoti razgaljena. To pomeni, da izgine z nje ves sneg oziroma ledeniški firn minule zime. V tem času je tudi le še izjemoma povezan s svojim spodnjim, severozahodnim podaljškom.

Na podlagi zadnjih meritev (15.10.2007) oddaljenosti roba ledenika do izbranih standardnih točk z laserskim razdaljemerom (Preglednica 2) se je pokazal nadaljnji trend krčenja in tanjšanja ledenika. Na večini markacij, v preglednici 2 so predstavljene le izbrane, je bil dosežen največji odmik ledeniškega roba. Morda podatki o površini ne kažejo dovolj slikovito, kako močno je krčenje ledenika pod Skuto, saj je bila njegova površina v preteklosti precej bolj stalna (Košir 1986). Bolj kot upadanje površine je korenito zmanjševanje debeline ledenika oziroma njegove prostornine.

Preglednica 2 : Razdalje ( $\mathrm{m}$ ) do izbranih markacij na obodu ledenika pod Skuto med letoma 1994-2006.

Table 2: Distances (in metres) to selected marks around the Skuta glacier in the period 1994-2006.

\begin{tabular}{|l|r|r|r|r|r|r|r|r|}
\hline MARKACIJE (oznaka) & $\mathrm{F}$ & $94^{3}$ & $94^{4}$ & $95^{4}$ & $94^{7}$ & $94^{10}$ & $94^{12}$ & $85=92^{\text {op }}$ \\
\hline 1994 & $-22,5$ & 0 & 0 & - & 0 & 0 & 0 & $-9,5$ \\
\hline 1995 & $-16,5$ & $+1,9 \mathrm{x}$ & $-0,5$ & $-1,0$ & $+3,5 \mathrm{x}$ & $+1,0 \mathrm{x}$ & $+1,0$ & $-4,0$ \\
\hline 1996 & $-17,5$ & $-0,4$ & $-1,9$ & $\mathrm{x}$ & $-0,5^{*}$ & $+2,0 \mathrm{x}$ & $-0,5$ & $-8,0$ \\
\hline
\end{tabular}




\begin{tabular}{|l|r|r|r|r|r|r|r|r|}
\hline 1997 & $-22,9$ & $-1,3$ & $-2,0$ & $\mathrm{x}$ & $-0,9$ & $-1,8$ & $-1,1$ & $-27,6$ \\
\hline 1998 & $-22,6$ & $-1,2$ & $-3,6$ & $-4,0$ & $-3,5^{*}$ & $-2,5$ & $-0,7$ & $-6,0$ \\
\hline 1999 & $-24,3$ & $-5,2$ & $-12,7$ & $-17^{*}$ & $-7,0^{*}$ & $\sim$ & $-3,2$ & $-31,0$ \\
\hline 2000 & \multicolumn{7}{|c|}{ N i b i l o m e r i t e v / $\mathrm{n} \mathrm{o} \mathrm{m} \mathrm{e} \mathrm{a} \mathrm{s} \mathrm{u} \mathrm{r} \mathrm{e} \mathrm{m} \mathrm{e} \mathrm{n} \mathrm{t} \mathrm{s}$} \\
\hline 2001 & $-17,0$ & $(\mathrm{x})$ & $-3,5$ & $(\mathrm{x})$ & $-3,6$ & $(\mathrm{x})$ & $-7,0 \mathrm{x}$ & $-9,3$ \\
\hline 2002 & $-30,0 \#$ & $-4,5$ & $-3^{*}$ & $-8^{*}$ & $-8^{*}$ & $-30-35^{*}$ & $\sim$ & $-57,0$ \\
\hline 2003 & $-28 \#$ & -8 & -47 & -35 & - & $\sim$ & $\sim$ & $-60 \#$ \\
\hline 2004 & -12 & $+1 \mathrm{x}$ & $-4,5$ & $-20^{*}$ & -10 & -3 & $+1-2 \mathrm{x}$ & -4 \\
\hline 2005 & $-23,5$ & $-6,7$ & $-25,8$ & $-40,5$ & $-20,7$ & $\sim$ & $-1,5$ & $-15,8$ \\
\hline 2006 & -12 & -3 & -12 & -21 & -9 & -3 & $\mathrm{x}$ & -5 \\
\hline 2007 & $-24,9$ & $-4,8$ & -23 & $-33,5$ & $-19,3$ & -26 & $-3,3$ & $-31,5$ \\
\hline
\end{tabular}

Vir: Arhiv GIAM ZRC SAZU.

Legenda (vse razdalje so $v \mathrm{~m})$ :

- $\quad$ ni podatka

- 5 pod markacijo (upadanje)

$+5 \quad$ nad markacijo (naraščanje)

$x \quad$ markacija ni vidna (pokrita z ledom/srenom/snegom/gruščem)

$\pm 1,0 x \quad$ natančna ocena razdalje prek navezave na druge markacije

$\quad$ markacija ni bila primerna za izvajanje meritev

* $\quad$ ocena razdalje (točka je nedostopna)

\# $\quad$ led je skrit pod gruščem (ne da se natančno ugotoviti obseg/rob ledu)

op močnejše kolebanje je posledica občasnega proženja snežnih plazov

\section{DEBELINA IN PROSTORNINA LEDENIKA}

Pri meritvah na ledeniku pod Skuto leta 2006 (22. - 24. septembra) smo namenili osrednjo pozornost izmeri debeline ledenika. S pomočjo sodelavca Komisije za glaciologijo pri Bavarski akademiji znanosti iz Münchna (Nemčija) in hkrati tudi konstruktorja posebne parne vrtalne naprave (Heuckejev ledni vrtalnik; http://www.zrc-sazu.si/giam/skuta_zanimi vosti.htm) smo napravili več kot 15 vrtin skozi ledeniško telo.

Ob začetku meritev pred 60 leti je bila ledeniška površina več deset metrov nad današnjo (Košir in Šifrer 1976), kar kaže nekaj starih markacij. Te so bile nekdaj v dosegu roke, zdaj pa bi terjal vzpon do njih zahtevnejše plezanje v dolžini 1-1,5 raztežaja plezalne vrvi (okrog 40-60 m). Rezultati so pokazali (Preglednica 3), da je povprečna skupna debelina ledenika, natančneje ledeniškega firna in ledu od 5 do $9 \mathrm{~m}$, povprečna debelina ledeniškega ledu pa je od 5 do $7 \mathrm{~m}$.

Debelino ledenika smo izmerili (Gabrovec in sod. 2006) s pomočjo dveh podolžnih prerezov v smeri 340 in $310^{\circ}$ (Slika 4). Na zahodnem prerezu, desno od osrednjega dela ledenika, smo napravili šest glavnih vrtin. Povprečna globina je bila $8,8 \mathrm{~m}$, pri čemer je bila izmerjena najmanjša, $4,8 \mathrm{~m}$ v najnižji vrtini, najgloblja z $11,7 \mathrm{~m}$ pa pri vrtini številka 3 . Na vzhodnem prerezu, levo od osrednjega dela ledenika, smo napravili štiri glavne vrtine. Povprečna globina je bila $5,1 \mathrm{~m}$, pri čemer je bila izmerjena najmanjša $(4,5 \mathrm{~m}) \mathrm{v}$ drugi vrtini (gledano od spodaj navzgor), največja $6,4 \mathrm{~m}$ pa pri najvišji vrtini. 
Preglednica 3: Debelina ledenika pod Skuto, izmerjena v dveh prerezih (prim. sliko 3).

Table 3: Thickness of the Skuta glacier in two longitudinal profiles (See fig. 3).

\begin{tabular}{|c|c|c|c|c|c|}
\hline Oznaka točke & $\begin{array}{l}\text { Nadm. višina } \\
\text { točke (m) }\end{array}$ & $\begin{array}{c}\text { Naklon } \\
\text { (v stopinjah) }\end{array}$ & $\begin{array}{l}\text { Debelina firna } \\
\text { (m) }\end{array}$ & $\begin{array}{l}\text { Debelina ledu } \\
\text { (m) }\end{array}$ & $\begin{array}{c}\text { Skupna } \\
\text { debelina (m) }\end{array}$ \\
\hline $\begin{array}{c}\text { Zah. prerez } \\
2\end{array}$ & 2085 & 28 & 2,2 & 9,1 & 11,3 \\
\hline 1 & 2076 & 23,5 & 1,5 & 8,5 & $10^{*}$ \\
\hline 3 & 2069 & 22,5 & 1,9 & 9,8 & 11,7 \\
\hline 4 & 2060 & 24 & 2 & 5,6 & 7,6 \\
\hline 5 & 2051 & 25,5 & 2,7 & 5 & 7,7 \\
\hline $5 \mathrm{a}$ & 2043 & 25 & 0 & 4,8 & 4,8 \\
\hline smer prereza & $340^{\circ}$ & povprečno & 1,7 & 7,1 & 8,85 \\
\hline $\begin{array}{c}\text { Vzh. prerez } \\
6\end{array}$ & 2082 & 33 & & & \\
\hline 7 & 2070 & 33 & - & 6,4 & 6,4 \\
\hline 8 & 2060 & 24 & - & 4,9 & 4,9 \\
\hline 9 & 2053 & 22,5 & - & 4,5 & 4,5 \\
\hline 10 & 2043 & 24 & - & 4,7 & 4,7 \\
\hline smer prereza & $310^{\circ}$ & povprečno & - & 5,1 & 5,125 \\
\hline
\end{tabular}

* Pri točki 1 je bil pod vsemi plastmi prazen prostor (podledeniška jama), do skalne podlage nismo prišli tudi, ko smo potisnili cev do najgloblje oznake $13 \mathrm{~m}$. Po navedbah konstruktorja obstaja možnost, da se začne cev v jamskem prostoru nekontrolirano zvijati.

Iz tega lahko sklepamo, da je povprečna globina ledenika okoli $7 \mathrm{~m}$, največja pa okoli $12 \mathrm{~m}$ ter da je zahodna polovica ledenika debelejša od vzhodne. Na temelju podolžnih prerezov na nadmorski višini od 2043 do 2085 m in prečnih razsežnosti ledenika smo izračunali, da je bila njegova prostornina leta 2006 nekaj manj kot $80.000 \mathrm{~m}^{3}$ (Gabrovec in sod. 2006). $\mathrm{Na}$ osnovi teh podatkov lahko potrdimo, da ledenik pod Skuto ni samo večji, temveč tudi debelejši od Triglavskega ledenika. Povprečna debelina slednjega, izračunana na osnovi 14 prerezov, je bila leta 2000 okrog $3 \mathrm{~m}$, največja pa $9,5 \mathrm{~m}$ (Gabrovec 1998).

Ugotovili smo že, da se na posameznih delih ledenik lahko letno stanjša tudi 1-1,5 m. V letu 2006 smo vstavili v nekatere od vrtin obeh prerezov nekaj palic za merjenje hitrosti zniževanja ledeniške površine oziroma za intenzivnost ablacije. Dve od petih palic, ki smo jih vstavili v vrtine vzhodnega prereza, smo našli ob zadnjem obisku ledenika leta 2007 (Pavšek 1994-2007). Meritve so pokazale, da se je ledenik na tem delu v nekaj več kot letu dni stanjšal za $0,7 \mathrm{~m}$. Upoštevajoč preračunano debelino ledenika (Preglednica 3) pri točki $8 \mathrm{v}$ letu 2007 (4,2 m), lahko domnevamo, da bo ob enaki dinamiki zniževanja ledeniškega površja kot smo ji bili priča med meritvami v letih 2006 in 2007, vzhodni del ledenika izginil v naslednjih šestih letih. Pri tem je treba upoštevati, da je bila zima 2005/06 precej hladna in snežna, naslednja (2006/07) pa skupaj z njej sledečo pomladjo in poletjem 2007 med najbolj suhimi in predvsem toplimi. Zadnje ugotovitve kažejo (Spletni arhiv ARSO), da je bilo leto 2007 med najtoplejšimi po letu 1851, odkar imamo na voljo podatke za Ljubljano. Tudi 
večina drugih glavnih meteoroloških postaj po Sloveniji z dolgoletnim podatkovnim nizom beleži leto 2007 med petimi najtoplejšimi (Kredarica leta 2007: srednja letna temperatura zraka $-0,3{ }^{\circ} \mathrm{C},+1,0^{\circ} \mathrm{C}$ odstopanje od dolgoletnega povprečja, 5. mesto v podatkovnem nizu 1955-2007).

Slika 4: Shematska predstavitev poteka obeh prerezov za izmero debeline ledenika pod Skuto (foto: Miha Pavšek; grafika: Blaž Komac).

Figure 4: Schematic presentation of both longitudinal profiles for the glacier thickness measurement (Photo: Miha Pavšek; Graphics: Blaž Komac).

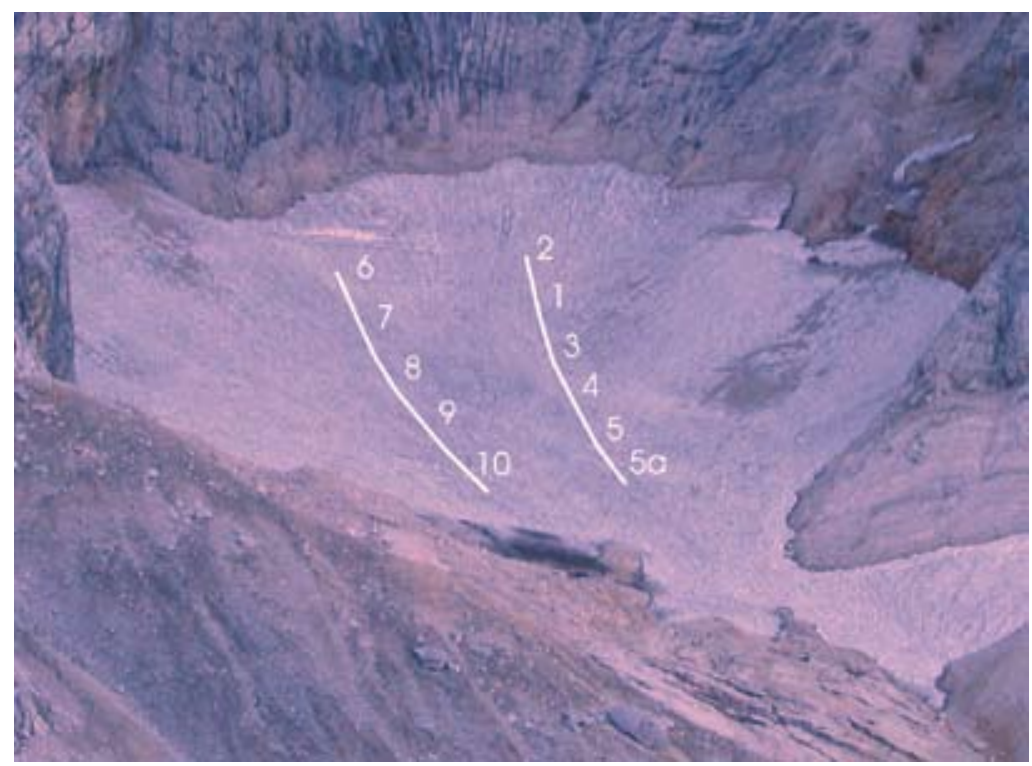

\section{IZBRANI METEOROLOŠKI PODATKI IN LEDENIŠKA DINAMIKA}

Največjo povezanost podnebja in ledenikov kažejo poleg sončnega obsevanja tudi temperaturne in padavinske razmere. Problem ledenika pod Skuto je, da ni v bližini primerljive meteorološke postaje, saj je na Zgornjem Jezerskem le padavinska, Krvavec pa je na nekoliko nižji nadmorski višini in na prisojni strani Kamniško-Savinjskih Alp.

V prihodnje si bomo lahko pomagali s podatki lavinske avtomatske meteorološke postaje na bližnjem Obirju, zahodno od Železne Kaple v Avstriji. Tu so, na nadmorski višini 2025 m (Rainerschutzhaus) in na Ojstrcu (2139 m), najvišjem vrhu Obirja, namestili naprave, ki beležijo temperaturne, vlažnostne, vetrovne in snežne razmere. Postaja je pričela $\mathrm{z}$ obratovanjem 14. februarja 2006. Že ob rednih letnih meritvah tega leta smo ugotovili, da so temperaturni podatki s spodnje postaje povsem primerljivi. Podatke $\mathrm{z}$ vršne postaje pa bomo lahko uporabili za kontrolo oziroma za predstavitev razmer na najvišji točki ledenika pod Skuto. 
Tokrat pa smo si pomagali (Preglednice 4-6) še s podatki (Spletni arhiv ARSO) za padavinsko postajo Zgornje Jezersko in klimatološko postajo na Kredarici. Za obe smo vzeli podatke za štirinajstletni niz 1993/94-2006/07, odkar redno sodelujem pri vsakoletnih meritvah. Padavinski podatki kažejo (Preglednica 4), da je pri količini padavin v redilni dobi ledenika največja spremenljivost v novembru in marcu. Novembra in aprila pa je največ padavin, ki pa so lahko občasno do pogosto tudi v obliki dežja. Dvig povprečnih temperatur je namreč povlekel za seboj tudi dvig meje sneženja ob vsakokratne padavinskem vremenskem dogajanju. V splošnem je za redilno dobo ledenika značilna velika spremenljivost količine padavin. Prav od slednje pa je v veliki meri odvisno tudi vsakoletno stanje ledenika ob koncu talilne dobe. Vsekakor bo potrebno v prihodnje analizirati še nekatere meteorološke kazalce za celotno opazovalno obdobje 1948-2007, oziroma vsaj za zadnji dve desetletji, odkar beležimo občuten dvig temperature in njegove posledice. Upoštevati moramo, da je na samem ledeniku zaradi orografskega učinka padavin še precej več, kot nam kažejo podatki za najbližjo dolinsko postajo. Po letu 2000 je opazen trend zmanjševanja skupne količine padavin $\mathrm{v}$ redilnem obdobju, kar sovpada $\mathrm{z}$ vedno bolj pogostimi suhimi zimami.

Preglednica 4: Mesečna količina padavin ( $\mathrm{mm}$ ) v redilni dobi ledenika (november - april) na merilni postaji Zgornje Jezersko (879 m) med sezonami 1993/94 in 2005/2006.

Table 4: Mean monthly amount of precipitation ( $\mathrm{mm}$ ) in accumulation period (November-April) of the glacier on meteorological station Zgornje Jezersko (879 m) between seasons 1993/94 and 2005/2006.

\begin{tabular}{|c|c|c|c|c|c|c|c|c|c|c|c|c|c|c|c|}
\hline 1993-2007 & $\frac{\hbar}{\text { ๙ે }}$ & $\frac{\check{\alpha}}{\partial}$ & 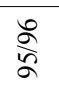 & ڤิ & $\frac{\infty}{\stackrel{\varsigma}{a}}$ & $\frac{\stackrel{\partial}{\infty}}{\stackrel{\infty}{ }}$ & ஓু & & $\stackrel{\Im}{\stackrel{\sigma}{\sigma}}$ & $\underset{\widehat{\delta}}{\tilde{\delta}}$ & 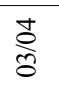 & $\begin{array}{l}2 \\
\frac{1}{0}\end{array}$ & $\frac{8}{8}$ & $\stackrel{5}{8}$ & $\stackrel{\wp}{\&}$ \\
\hline & 127 & 92 & 102 & 295 & 361 & 179 & 97 & 831 & 78 & 218 & 284 & 98 & 188 & 58 & 215 \\
\hline & 226 & 96 & 191 & 64 & 226 & 28 & 147 & 180 & 42 & 98 & 123 & 161 & 157 & 102 & 132 \\
\hline Janua & 157 & 118 & 74 & 117 & 34 & 54 & 3 & 230 & 12 & 96 & 90 & 22 & 42 & 78 & 81 \\
\hline Februar & 45 & 163 & 119 & 34 & 3 & 80 & 23 & 33 & 72 & 50 & 140 & 38 & 78 & 95 & 70 \\
\hline & 30 & 190 & 22 & 30 & 54 & 128 & 165 & 386 & 88 & 2 & 96 & 50 & 209 & 169 & 116 \\
\hline & בים & 53 & 122 & 75 & 256 & 245 & 19 & 143 & 159 & 108 & 135 & 205 & 168 & 23 & 147 \\
\hline SKUPAJ & 808 & 712 & 630 & 615 & 934 & 714 & 577 & 1803 & 451 & 573 & 868 & 574 & 842 & 525 & 75 \\
\hline
\end{tabular}

$M P O=$ mesečno povprečje obdobja / season's mean monthly average.

Zanimiva je tudi predstavitev nekaterih temperaturnih kazalcev za primerljivo postajo na Kredarici (Preglednici 5 in 6). V primerjavi z dolgoletnim povprečjem je za obdobje 1994-2007 opazen precejšen dvig povprečnih temperatur vseh poletnih mesecev (Preglednica 5) in predvsem povprečne temperature meteorološkega poletja (junij-avgust). Temperaturni presežek obravnavanega obdobja glede na dolgoletno povprečje predhodnega obdobja (1961-1990) je kar $1,4{ }^{\circ} \mathrm{C}$. To potrjuje ugotovitve o postopnem dvigu temperatur v zadnjih dveh desetletjih v gorskih pokrajinah Slovenije. V tem pogledu še posebej izstopa poletje 2003 (zlasti najtoplejši avgust, ki je ponavadi najhladnejši od vseh treh mesecev meteorološkega poletja), ki je preseglo povprečje znotraj obdobja $1994-2007$ za $2,7{ }^{\circ} \mathrm{C}$, obdobja $1960-1990$ pa kar za 4,1 ${ }^{\circ} \mathrm{C}$. Precej podpovprečne padavine v redilni in izjemno 
nadpovprečne temperature v talilni dobi so povzročile, da si ledenik od tega ni opomogel vse do zadnjih meritev leta 2007.

Preglednica 5: Povprečne mesečne in poletne temperature $\left({ }^{\circ} \mathrm{C}\right)$ na Kredarici $(2515 \mathrm{~m})$ med letoma 1994 in 2006.

Table 5: Mean monthly and summer seasonal temperatures $\left({ }^{\circ} \mathrm{C}\right)$ on meteorological station of Kredarica $(2515 \mathrm{~m})$ between 1994 in 2006.

\begin{tabular}{|c|c|c|c|c|c|c|c|c|c|c|c|c|c|c|c|c|}
\hline $\begin{array}{l}1994- \\
2007\end{array}$ & 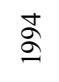 & $\stackrel{\text { }}{\varrho}$ & よ̊ & $\widehat{\partial}$ & $\stackrel{\infty}{\stackrel{2}{\varrho}}$ & ڤे & ஓి & 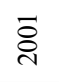 & ఠิ & ڤิ) & ठั & $\stackrel{n}{\stackrel{ి}{े}}$ & ஜ̊ & ڤ్ & 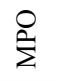 & $\sum_{\Delta}^{a}$ \\
\hline & & & 5,1 & 4,1 & $5, \mathrm{c}$ & 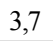 & & 3,3 & & 8,9 & 41 & & & 5,6 & 5,1 & 3,2 \\
\hline Julij & & 8,5 & 5,1 & 5,3 & 7,2 & 6,3 & 4,4 & 6,9 & 6,9 & 7,9 & 6,3 & 7 & 9,1 & 7,5 & 6,9 & 5,8 \\
\hline & 8,6 & 5,2 & 5,3 & 6,2 & 7,9 & 6,9 & 8,5 & 8,6 & 6,1 & 10,2 & 7, & 4,7 & 3,5 & 6,8 & 6,8 & 5,8 \\
\hline POLETJE & 7,1 & 5,4 & 5,2 & 5,2 & 6,9 & 5,6 & 6,5 & 6,3 & 6,6 & 9,0 & 5,8 & 5,5 & 5,9 & 6,6 & 6,3 & 4, \\
\hline
\end{tabular}

$M P O=$ mesečno povprečje obdobja 1994-2007 / monthly average 1994-2007.

$D M P=$ dolgoletno mesečno povprečje 1961-1990 / longterm monthly average 1961-1990.

Največji dvig temperatur v zadnjem klimatološkem obdobju (Preglednica 6) je prisoten ravno poleti oziroma $\mathrm{v}$ letnem času, ki je z vidika temperaturnih kazalcev najpomembnejši za ohranjanje ledenika. Bolj kot zimski je pomemben precejšnji dvig povprečne temperature spomladanskega trimesečja. Na nadmorski višini, kjer leži ledenik, pomeni zimski dvig, da pade večina padavin v obliki snega, spomladanski pa je povzročil, da v zadnjem desetletju in pol v tem letnem času dežuje pogosteje kot nekdaj. Tako je sneg še bolj premočen in občutljiv na poletno segrevanje ozračja in neposredno sončno obsevanje.

Preglednica 6: Statistično pomembna odstopanja (mastni tisk) spremembepovprečne temperature na Kredarici (2515 m) po posameznih letnih časih $\left({ }^{\circ} \mathrm{C}\right)$ v 30-letnem obdobju 1971-2000.

Table 6: Statistically important deviation (bold) of mean seasonal temperatures $\left({ }^{\circ} \mathrm{C}\right)$ on meteorological station of Kredarica (2515 m) during 1971-2000 period.

\begin{tabular}{|l|c|c|c|c|c|}
\hline METEOROLOŠKA POSTAJA / LETO & JESEN & ZIMA & POMLAD & POLETJE & LETO \\
\hline Kredarica $(2515 \mathrm{~m})$ & 0,5 & 1,7 & 1,5 & 2,0 & 1,4 \\
\hline
\end{tabular}

Morebiten dvig temperatur bo v prihodnje povzročil nadaljnje dvigovanje vsakokratne meje sneženja. Tako bo lahko v prihodnje, kljub podobni ali celo večji količini padavin, teh v obliki snega še manj kot do sedaj.

Z natančno analizo stopnje povezanosti med posameznimi vremenskimi in podnebnimi kazalci ter spreminjanjem površine, debeline in oddaljenosti od markacij ob robu ledenika bomo skušali v prihodnje še podrobneje osvetliti vzroke, posledice in značilnosti kolebanja obeh slovenskih ledenikov vse od leta 1946, odkar potekajo redne letne meritve. Možnost opazovanja izginotja enega ali obeh naših ledenikov oziroma tistega, kar je od njiju še ostalo, je poleg raziskovalnega izziva tudi priložnost za seznanjanje širše javnosti z obsegom in posledicami podnebnih sprememb na širšem območju Alp. 


\section{SKLEP}

Ledeniki v Alpah in drugod po svetu se v zadnjih dveh desetletjih zelo krčijo. Gledano skozi geografske oči pa je neizpodbitno dejstvo, da gre za naraven proces, saj so bila tudi v geološki zgodovini Zemlje toplejša in hladnejša obdobja. Očitno je, da smo po tako imenovani mali ledeni dobi priča spet nekoliko toplejšemu podnebju oziroma obdobju. Pri tem pa je vse več podatkov, ki kažejo na to, da smo prvič v zgodovini povzročitelji v večji ali manjši meri ljudje sami. Ob nadaljevanju svetovnega trenda dviga temperatur v naslednjih desetletjih se nam za ledenik pod Skuto kaže ugotovitev, da je ob podobnem nadaljnjem trendu krčenja pričakovati, da bo tudi ta ledeniška krpa, kot pred njo mnoge druge pri nas in po svetu, kmalu izginila. Pri tem bo izginil najprej vzhodni, potem pa še zahodni del ledenika.

Ledenik pod Skuto je zdaj večji in debelejši od svojega, nekaj več kot $50 \mathrm{~km}$ zahodneje ležečega soseda pod Triglavom. Zaradi sorazmerno majhne velikosti obeh in velike spremenljivosti meteoroloških kazalcev pa se lahko v prihodnje ta razmerja hitro spremenijo. Videti je, da je z globalnim segrevanjem ozračja vse bolj pomembna senčna lega ledenika.

Procesi in stanje ledenika pod Skuto so le del normalnega naravnega dogajanja, predvsem podnebnih sprememb v daljšem časovnem obdobju. To se je domnevno začelo pred nekaj stoletji, ko je začel ledenik nastajati in se bo po vsej verjetnosti končalo v naslednjem desetletju, ko bo edina ledeniška zaplata v Kamniško-Savinjskih Alpah, in morda takrat že tudi pri nas, izginila. Pod njo se bo odprlo z ledeniško erozijo in korozijo agresivne ledeniške vode preoblikovano površje, za raziskovanje morda nič kaj dosti manj zanimivo od tega, kar je bilo na njem pred tem. Za precejšen del javnosti tragika, za geografa pa odlična priložnost je prav to, da se vse skupaj dogaja tukaj in zdaj, pred našimi očmi, zato jo velja zagrabiti z obema rokama.

\section{Viri in literatura}

Arhiv Geografskega inštituta Antona Melika ZRC SAZU 1946-2007. Redna letna poročila in dokumentacija o Triglavskem ledeniku in ledeniku pod Skuto. Ljubljana.

Gabrovec, M. 1998. Triglavski ledenik med letoma 1986 in 1998. Geografski zbornik, 38, 89-110. Ljubljana.

Gabrovec, M. in sod. 2005. Triglavski ledenik kot pokazatelj podnebnih sprememb in opis rednih meritev ledenika pod Skuto (projekt L6-7136). Prvo vmesno poročilo. Agencija RS za okolje. Ljubljana.

Gabrovec, M. in sod. 2006. Triglavski ledenik kot pokazatelj podnebnih sprememb in opis rednih meritev ledenika pod Skuto (projekt L6-7136). Drugo vmesno poročilo. Agencija RS za okolje. Ljubljana.

Košir, D., Šifrer, M. 1976. Ledenik pod Skuto od leta 1955 do leta 1973. Geografski zbornik, 15, 241-269. Ljubljana.

Košir, D. 1986. Ledenik pod Skuto v letih 1974-1985. Geografski zbornik, 26, 141-151. Ljubljana.

Meze, D. 1955. Ledenik na Skuti. Poročilo o opazovanjih v letih 1946-54. Geografski zbornik 3, 77-114. Ljubljana. 
Pavšek, M. 1994-2007. Redna letna poročila o opazovanjih in meritvah ledenika pod Skuto (delovno gradivo). Arhiv GIAM ZRC SAZU. Ljubljana.

Pavšek, M. 2004. Ledenik pod Skuto: ledeniški dragulj na senčni strani Kamniško-Savinjskih Alp. Geografski obzornik, 51, 3, 11-17. Ljubljana.

Pavšek, M. 2004. Nivologija (prispevek za Geografski terminološki slovar). Ljubljana.

Pavšek, M. 2005. Triglavski 'zelenec' še vedno vztraja. Redne letne meritve Triglavskega ledenika v letu 2005. Planinski vestnik, 111, 4, 46-47. Ljubljana.

Spletni arhiv Agencije Republike Slovenije za okolje (ARSO) z meteorološkimi podatki (http://www.arso.gov.si/vreme/podnebje/).

\section{THE SKUTA GLACIER AS AN INDICATOR OF CLIMATE CHANGES IN SLOVENIAN PART OF THE ALPS}

\section{Summary}

In the Slovenian part of the Alps only two glaciers are still present at a relatively low elevation: one is below the peak of Triglav $(2864 \mathrm{~m})$ and the other below (the peak of) Skuta (2532 m). Their present areas do not exceed one hectare, thus it is appropriate to name them glacier patches. It is in 2006 exactly six decades since the researchers of the Anton Melik Geographical Institute SRC SASA have been monitoring them.

Mass climbing on the Triglav, the highest Slovenian peak and the nearby meteorological observatory on Kredarica are the main reasons for the greater publicity of the Triglav glacier. In the past, this glacier in Julian Alps was always larger than its eastern neighbor in KamnikSavinja Alps. Due to climate changes, especially permanent temperature rise, this situation changed in the beginning of the $21^{\text {st }}$ century. In 2003, after extreme hot summer period, the measurements on both glaciers confirmed our, a few years earlier given forecast.

The annual changing of the glaciers is the consequence of a complicated combination of the effects of various climatic factors in the warm and cold periods of the year, its thawing and growing periods.

Data on the surface area (Table 1) of the Skuta glacier, including the oldest during more than sixty years of uninterrupted monitoring and measuring, has been acquired in various ways. At first, annual measurements included measuring of the distances from the ice to measurement points placed by the researchers on the margin of the glacier (Table 2). In the last decade, periodically, classical geodetic measurements were made with a theodolite, at first in 1997, and later in 2003 and 2007. The rapid shrinking of the Skuta glacier in the last two decades is undoubtedly connected to the rising temperature in this period. On the other hand, abundant snow precipitation in 2001 and 2006 temporarily stopped its shrinking and a similar event happened in the 1970's.

We first used the steam ice drill on the Skuta glacier in 2006. On two cross-sections, we have made 10 holes and left, in some of them, some ablation-measuring sticks. The drilling results (Table 3) showed that this glacier is even thicker (average depth $7 \mathrm{~m}$, largest 11,7 m) than the Triglav glacier (average depth $3 \mathrm{~m}$, largest 9,5 $\mathrm{m}$ in year 2000). From the boreholes 
we acquired data on the formation of the slope or basin where the glacier is situated. The surface and distance data of the glacier, together with the data on its thickness, enabled us for the first time to estimate its volume on about $80.000 \mathrm{~m}^{3}$. If the surface of the glacier shrank to one third of its original size in nearly six decades, its volume shrank to less than one tenth of the original volume. In some parts, the Skuta glacier thinned for 1-1,5 m per year. We got a confirmation of this within last regular measurements in 2007 by checking some of the ablation-measuring sticks, which pointed to $0,7 \mathrm{~m}$ decrease of the glacier surface in the last year.

If the same trend will persist, the eastern part of the glacier will most likely disappear within the next six years. This will probably not happen because some meteorological parameters for the last decade and a half (Tables 4 and 5) show us a greater precipitation and temperature variability. For the Skuta glacier the selected data from the meteorological station on Kredarica in Julian Alps $(2515 \mathrm{~m})$ is clear proof of this. November and April are the months with the greatest amount of precipitation, thus with temperature rise a great part of them can fall in a liquid form and not as snow. After 2000, there is a significant lack of precipitation in the glacier's accumulation period.

On the other hand, the summer seasonal temperature data give us undoubted evidence of global warming. The average summer temperature (June - August) in period 1994-2007 is $1,4{ }^{\circ} \mathrm{C}$ higher than the same average for previous $1961-1990$ period. The statistically important rise of average summer temperature in the period $1971-2000$ is $2,0^{\circ} \mathrm{C}$. In the future, we will be able to use the data from automatic meteorological station on the peak of Obir (2139 m) in neighboring Austria, 15 kilometers north-northwest from the glacier, which belongs to Carinthian Avalanche Service. Also, a selected meteorological data for a longer period will be analyzed in the near future.

Last measurements of both Slovenian glaciers show that the shadow position of the Skuta glacier is from year to year of even greater importance. The processes and state of the glacier are a part of normal natural dynamics, especially climate changes in longer period. This process began a few centuries ago, when the glacier started to taking a shape and will probably ends within the next decade when it will most likely disappear. For most public nearly a 'tragic' event is, from geographer's point of view, an excellent opportunity to monitor directly the process. At the same time, we are waiting that nature will uncover one of last parts of Earth surface. The relief, once hidden below the glacier, offers us a new challenges to research further and more in detail this small part of Slovenian mountainous landscapes. 